\title{
Activities at Early Childhood Centers in Ghana: Observations of Early Childhood Teacher-Trainees
}

\begin{tabular}{ll|l}
\hline Ahmed Abdulai & (iD \\
\hline${ }^{1}$ Department of Early Childhood Education University of Education, Winneba, Ghana &
\end{tabular}

\begin{abstract}
This study looked at activities at early childhood education centers in Ghana in the areas of; nature and use of curriculum, environmental conditions, pedagogical practices, and the nature and use of assessment. Using the quantitative research approach, 136 final year early childhood teacher-trainees engaged in teacher- internship practice in the 10 regions of Ghana administered a researcher designed observation checklist to a number of early childhood centers in the country. Findings that emerged were that participants were fairly satisfied with teaching and learning conditions at the different early childhood centers they visited, and that the curriculum used at the centers were relevant, meaningful, and based on learner's prior experiences. The early childhood environment was described as one that enhanced teaching and learning. Pedagogical practices as seen by participants was one that promotes learning, and also assessment tools were described as encouraging and appropriate. Despite this encouraging information presented by participants, shortfalls such as a one-fit-all curriculum, learners not allowed to learn at their own pace, lack of space for private learning at classrooms, as well as lack of parental involvement in evaluating assessment data also emerged in the findings. Based on these, the study provides a number of recommendations of which include the need for flexible curriculum to carry on board all learners, the need for training for educators in the area of manipulating the curriculum to meet individual learner needs, and also a rethink of early childhood classroom architectural design to accommodate the learning needs of all levels of learners.
\end{abstract}

Keywords: Early childhood education, Curriculum, Environment, Pedagogy, Assessment.

\section{Contents}

1. Introduction.

2. Statement of the Problem ...th.t.

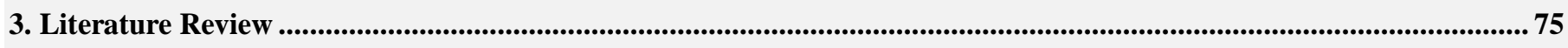

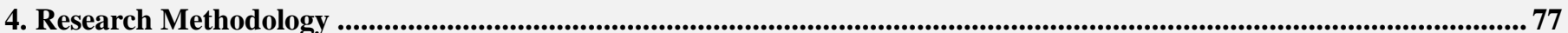

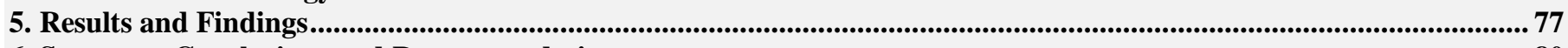

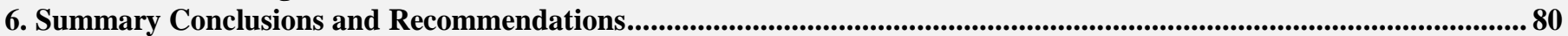

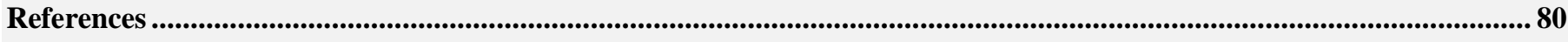

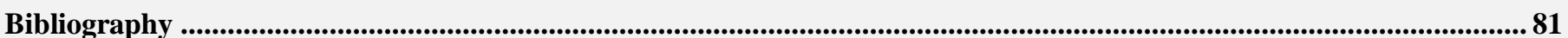

Citation | Ahmed Abdulai (2017). Activities at Early Childhood Centers in Ghana: Observations of Early Childhood Teacher-Trainees. Asian Journal of Education and Training, 3(1): 74-81.

DOI:

$\operatorname{ISSN}(\mathbf{E})$ :

Licensed:

Funding:

Competing Interests:

2519-5387

This work is licensed under a Creative Commons Attribution 3.0 License $(\mathrm{ccc}) \mathbf{E Y}$

This study received no specific financial support.

The author declares that there are no conflicts of interests regarding the publication of this paper.

The author confirms that the manuscript is an honest, accurate, and transparent account of the study was reported; that no

vital features of the study have been omitted; and that any discrepancies from the study as planned have been explained.

History:

Ethical:

Received: 24 March 2017/ Revised: 10 April 2017/ Accepted: 17 April 2017/ Published: 21 April 2017

Publisher:

Asian Online Journal Publishing Group 


\section{Introduction}

In the year 2003, under the auspices of an education reform program, the Ministry of Education and Sports; Ghana, issued an Education Strategic Plan (ESP, 2003-2015) to serve as a guiding principle in the attainment of its educational commitment as stated in the Millennium Development Goals (MDGs). Key areas contained in the ESP was access, quality and management of education as the driving force in Ghana's developmental aspirations. Of immense importance in this process was the incorporation of early childhood education into mainstream formal education. Early childhood education within the ambit of the ESP was to serve as the foundation of basic education in Ghana. Ghana's commitment to early childhood care and education even before the ESP was early childhood care and education being catered for in Ghana's constitution (1992 Constitution of Ghana; Act 38). In Ghana, early childhood education programs are represented as any program in a center or school, or any other facility that caters for the educational needs of children from 0-8 years old. Such programs include but not limited to child care centers, family child care homes, private and public schools, and kindergarten (Early Childhood Care and Education Policy, 2005).

Whiles Ghana's commitment to early childhood education as evidenced in the above policy initiatives are commendable, it is also instructive to investigate the extent to which Ghana's early childhood educational practices conform to Developmentally Appropriate Practices. Children's development and learning especially at the early childhood level have been of immense interest to Ghanaians. Professionals, parents, and policy makers in Ghana alike have increasingly been interested in the quality of services and the documentation of their effectiveness in early childhood programs. The extent to which quality is adhered to in the dispensation of early childhood education programs in Ghana has gained much attention in recent times. This desire is partly informed by research; that longterm effects of early childhood programs indicate that children who attend high quality child care programs even at the very young age demonstrate positive outcomes than their counterparts who attend low quality programs (Barnett and Hustedt, 2003). Hence, it becomes imperative to find out what is happening at the early childhood classroom and the extent to which such practices adheres to the development of the learner?

Developmentally Appropriate Practices (DAP) as defined by La Paro et al. (1998) represents a philosophical positioning that children actively learn and construct their own knowledge when allowed to interact with their peers, teachers, and materials, and also that each child has his/her own unique developmental characteristics and should be allowed to develop at his/her own pace. Though there are some who have argued against the universality of DAP across countries due to unique socio-cultural happenings (see; (O'Brien, 1996; Lubeck, 1998)) there is unanimity that best standards relative to early childhood education cannot be realized without adherence to certain basic indispensable quality education variables such as; class size with low ratios of children to teachers, teacher background and training, child focused communication, the nature and use of the curriculum, classroom processes, mode and means of assessment, parental involvement, and classroom and school environment (Bredekamp, 1987).

In this study, perspectives of early childhood teacher-trainees of the University of Education, Winneba who participated in an internship teaching practice in the different regions of Ghana on what pertain at the various early childhood centers where they did their internship programs are sought. In doing this, this study provides a snapshot of activities at the different early childhood centers in Ghana as presented by participants of this study, and that information gathered by this study do not represent what participants of this study present as their actions whiles at the different early childhood centers, instead what they present as having observed at the different centers they taught. Whiles this study sought to investigate what pertains at the early childhood level in Ghana as presented by early childhood teacher-trainees who embarked on teacher internship program from the University of Education, Winneba, it is important to state that such term as Developmentally Appropriate Practices was never used in an observation checklist administered by participants in the gathering of data for this study. Instead, participants were asked to respond to questions relative to activities they observed whiles at the different early childhood centers where they served as interns.

\section{Statement of the Problem}

As early childhood education became part of Ghana's educational program so too was the proliferation of early childhood centers especially by private and non-governmental organizations. Currently, it is the policy of the Government of Ghana that every public primary institution should have at least a two-class room early childhood center attached to it ECCEP (2005). This policy has led to an increase in the number of early childhood centers across the country. Activities at most of these centers in the direction of quality of services provided is mostly unknown. As a result, partly informed by the suggestion of Crosser (1996) that it is always wise for us as early childhood educators to take a step back and look at what we are doing in our preschool classroom, this study seeks to bring to the fore activities of early childhood centers in Ghana in the area of quality of services.

Whiles addressing the above problem, it is anticipated that this study will serve as a source of information in the practices of early childhood centers in Ghana in the areas of; the nature of curriculum at Ghanaian early childhood centers, the kind of early childhood environments in Ghana, instructional strategies used at the different early childhood centers in Ghana, and the place of assessments at Ghana's early childhood centers.

\section{Literature Review}

Literature review for this study is done in the areas of; curriculum in early childhood education, the environment in early childhood education, pedagogical practices at the early childhood level, and assessing the early child.

\subsection{Curriculum in Early Childhood Education}

Curriculum as a term is usually described as the totality of learning experiences encountered by the learner in a school (Tanner and Tanner, 1995). For Adentwi (2005) it constitutes educationally valuable experiences that the learner absorbs under the auspices of an educational institution. The consensus regarding what constitutes curriculum 
is represented as what is learnt, when it is learnt, and how it is learnt. Curriculum by all intent and purposes serves as the pivotal point around which an educational program guided by a school revolves.

When it comes to early childhood education, the widely accepted and best form of curriculum is what is described in the literature as child-centred curriculum. Pioneer early childhood educators such as John Dewey (18591952), Friedrich Froebel (1782 - 1852), and Maria Montessori (1870 -1952) have all advocated for a child centred curriculum. This form of curriculum according to Dewey is hinged on the needs and interests of the learner. Put differently, Froebel argues that learning should be one that emphasizes on the externalization of the child's innerself, because as Froebel presents it, every child has an inner spirituality, and the duty of the educational program represented in what is learnt and how it is learnt (curriculum) must help in the externalization of this innerspirituality. Indeed, the National Association for the Education of Young Children (NAEYC) in its publication on Developmentally Appropriate Practices at the early childhood level calls for practices that takes into consideration the needs of children (Bredekamp and Copple, 1997). The idea that learning at the early childhood level should be grounded in child-centeredness is definitely not disputed (O'Sullivan, 2004) In addition, there is also the argument that children learn with their affective and social domains, and as a result the early childhood curriculum should be one that establishes relationships between what is learnt in school and what pertains in society (Dewey, 1915). The concept of learning being a multisensory enterprise is also stressed in early childhood educational curriculum (Shams and Seitz, 2008). Dinnebeil et al. (2013) argue that the early childhood educational curriculum design should be one grounded in flexibility. Again, Play is also described as a critical and cardinal ingredient in every successful early childhood educational curriculum (Estes, 2004; Armstrong, 2006; Elliott, 2010).

In Ghana, basic education starts from kindergarten One (1). Kindergarten education serves as the only aspect of early childhood education represented in the Ghanaian formal educational program. Ghana's kindergarten education is guided by a uniform curriculum developed by the Ghana Education Service (Curriculum Research and Development Division) in collaboration with UNICEF; Ghana. This curriculum is used by all public/government funded kindergarten centers in Ghana. Ghana's kindergarten curriculum according to Abrompah (2010) aims at developing the totality of the learner shaped in physical, emotional, spiritual, and cognitive development. When it comes to private institutions relative to what kind of curriculum is used, there is not a single standardized type of curriculum.

\subsection{The Environment in Early Childhood Education}

The type of environment that characterizes every educational program has always been of concern to stakeholders involved in any educational program. Gandini (1998) points to the fact that physical environments impacts learning and development and as a result makes it very essential in any educational approach. This observation is seen as relevant and applicable to early childhood education (Tracey and Morrow, 2012). Learning environment is described by Tomlinson (2001) as how a classroom works and feels. The learning environment is seen as the totality of ingredients that makes teaching and learning effective and efficient. And this will include class room space, teacher- learner ratio, qualification of teachers and caliber of staff, availability of teaching learning materials, and the kind of relationship and connection between the school and community, and parents (Obiadike and Enemuo, 2013). Concerns of increasing teacher-child ratio especially at the early childhood level has persisted and continue to receive attention in the field of research (Dodge and Colker, 1992). In Ghana, these concerns are profound due to the limited number of qualified educators who teach at the early childhood level (Asemanyi and Wunku, 2007).

\subsection{Pedagogical Practices at the Early Childhood Level}

It is assumed by many that the success of every educational program is based in part by the pedagogical approach adopted for such program and this is particularly true when it comes to early childhood education. Pedagogy according Siraj-Blatchford (1999) represents the how or practice of educating. For the author, pedagogy refers to the instructional techniques and strategies which enables teaching and learning to take place, and that it should aim at providing opportunities for learners to acquire the skills, knowledge, attitudes and dispositions within a particular socio-cultural context. Instruction at the early childhood level is described as one that should be devoid of adult control; that is, giving of commands, asking questions with single right answers and providing instructions to the whole class instead of to individuals (Hayes et al., 1990). Early childhood pedagogical practices according to Hohman and Weikart (1995) should be shaped as active learning which for the authors is one based on where learners are encouraged to develop their unique patterns or interests, talents and goals with learning experiences presented in a manner where learners are able to master, generalize and retain what they learn and relate it to previous experiences. Herbert (2004) calls for a learner-centred pedagogical approach also known as child-centred learning at the early childhood level. This approach according to Herbert is one where learning mainly focuses on the needs and interests of the learner instead of that of teachers and administrators.

\subsection{Assessing the Early Child}

Assessment has always been an important component of early childhood education. It is described by Meisels (2001) as the process where comprehensive and ongoing information is gathered about learner's knowledge, skill level, and personality for the purposes of arriving at evaluative decisions. At the early childhood level, Neisworth and Bagnato (2004) are of the view that assessment methods of children should aim at supporting children's developmental changes. There is no doubt that children at the early childhood level learn differently from adults and as a result, Bredekamp and Rosegrant (1995) proposes that modes of assessing children should be one that is continual and ongoing with the aim of helping children develop positively. This means, the importance and relevance of assessment at the early childhood level definitely cannot be underestimated. Kellough and Kellough (1999) for instance argue that teaching and learning are reciprocal and that through assessment we are able to know if teaching is done well, just as we are also able to determine if the learner is also learning. These notwithstanding, there are 
some concerns raised about the capacity of early childhood educators to effectively administer assessment for learner's development. For example, Neisworth and Bagnato (2004) lament about the inability of some of the most skilled and experienced early childhood professionals to properly administer assessment due to their limitation in professional development.

In summary, the literature review reveals that curriculum being the center of every educational program should be one that at the early childhood level is child-centred and flexible aimed at using play as a means of realizing it. Again, the environment serves as an important and fundamental ingredient in early childhood education, and that teacher-learner ratio as well as the background and professional training of educators needs to be factored in every successful early childhood education program. In addition, since children are active learner's, instruction represented as pedagogical practices should be one of active learning and learner-centred. Finally, assessment which serves as a representation of gathering information about a learning program should emphasize on aiding the development of the learner. With these aforementioned themes emanating from the literature review, the study proceeds to address the below research questions:

1. How does Ghana's early childhood education curriculum stimulate learning?

2. To what extent does Ghana's early childhood education learning environment stimulate learning?

3. To what extent do instructional strategies of Ghana's early childhood education used to facilitate learning?

4. How do assessment procedures at Ghana's early childhood education program stimulate learning?

\section{Research Methodology}

This study is a quantitative research of the survey design where 136 early childhood teacher-trainees drawn from the University of Education, Winneba; Ghana presented their perspectives on happenings at early childhood educational centers in some selected schools in Ghana. The instrument for data collection was a researcher developed observation checklist. Participants prior to embarking on a six-month mandatory teaching internship program were taken through a two-hour training on how to administer an observation checklist on practices of early childhood centers that they will be performing their teaching practice. The sampling approach used was purposive sampling because participants had to be students of the University of Education, Winneba, and had to be in their final year at the department of early childhood education (Bachelor of Education, Early Childhood Education). Data analysis were done using descriptive statistics guided by the research questions that informed the study.

The research instrument gathered information in the arears of; participant's bio-data, curriculum practices at early childhood centers, the school environment, instructional strategies, and the mode and purpose of assessment at the early childhood centers visited by participants. Each section of the instrument consisted of a number of individual questions tailored towards addressing the research questions of this study. Using a Likert scale, participants indicated in their responses the existence of some variables relative to practices of early childhood education. The Likert scale is presented as; 1.2 - 1.7: To a Large Extent, 1.8- 2.3: Quite a Bit, 2.4 - 3.0: Not at All.

\section{Results and Findings}

Bio-data information of participants indicate that of the 136 participants who undertook this study, 98 were female, whiles 38 were male. Participants taught in all 10 regions of Ghana with majority teaching at the Central region. Also, most participants fell within the age bracket of 20-25 years old, and majority taught at the Kindergarten level, and at public/government schools.

In answering Research question 1, responses from participants aimed at determining the extent to which curriculum practices at early childhood education centers stimulated learning. Responses by participants relative to the above question was that to a large extent the curriculum is relevant, meaningful, and based on prior experiences allowing children to make connections. They agreed that the curriculum is integrated across all domains of child development - physical, social, emotional, linguistic, and cognitive. The overall average score was 1.69 as presented in Table 1.

Table-1. Early Childhood Curriculum Learning Facilities Descriptive Statistics

\begin{tabular}{|c|c|c|c|}
\hline & $\mathbf{N}$ & Mean & Std. Deviation \\
\hline The curriculum is designed to allow children to learn at their own pace. & 136 & 1.92 & 0.741 \\
\hline The curriculum is designed based on where each child is developmentally. & 136 & 1.89 & 0.685 \\
\hline Everyone is required to acquire the same skills and information. & 136 & 1.74 & 0.762 \\
\hline $\begin{array}{l}\text { The curriculum is integrated across all domains of child development - physical, } \\
\text { social, emotional, linguistic, and cognitive. }\end{array}$ & 136 & 1.45 & 0.581 \\
\hline $\begin{array}{l}\text { The curriculum is relevant, meaningful, and based on prior experiences allowing } \\
\text { children to make connections. }\end{array}$ & 136 & 1.43 & 0.54 \\
\hline Total & & 1.686 & 0.6618 \\
\hline
\end{tabular}

Source: Ahmed Abdulai

Also, participants fairly agreed that everyone is required to acquire the same skills and information as well as the curriculum being designed is based on where each learner is developmentally. These conclusions are presented in Figure 1. 
The curriculum is relevant, meaningful, and based on prior experiences allowing children to make connections.

The curriculum is integrated across all domains of child development - physical, social, emotional, linguistic, and cognitive.

veryone is required to acquire the same skills and information.

The curriculum is designed based on where each child is developmentally.

The curriculum is designed to allow children to learn at their own pace.

Source: Ahmed Abdulai

Figure-1. Early Childhood Curriculum Learning Facilities Mean Bar Chart

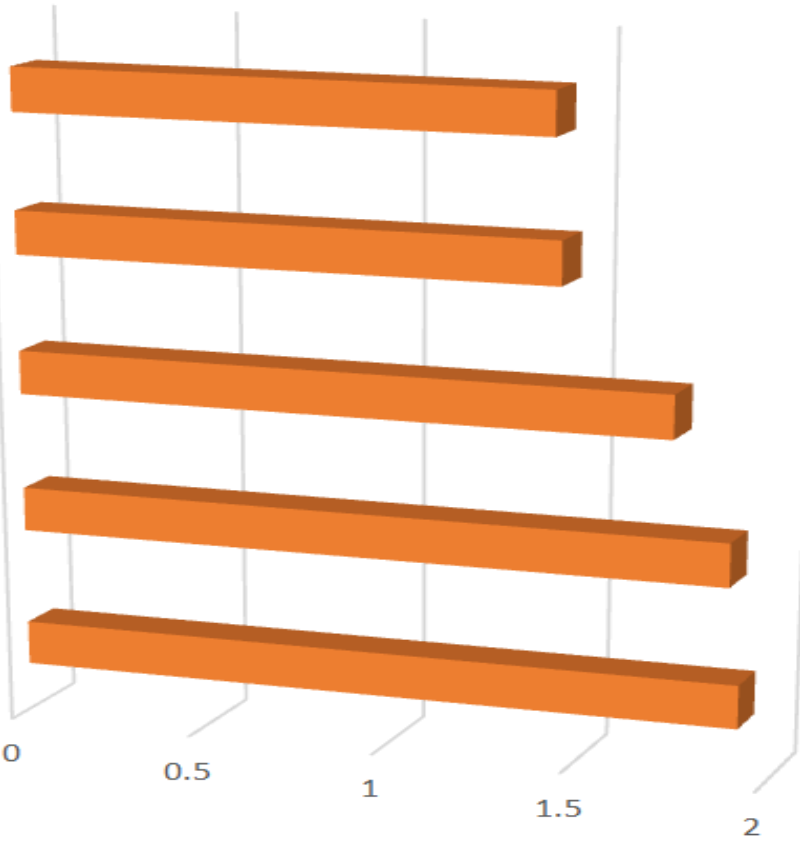

2

Regarding the effect of the early childhood environment in stimulating learning, respondents were fairly satisfied with an average score of 2.01. Generally, respondents agreed that learning environment of early childhood centers are appropriate and promote learning. Respondents acknowledged that the school environment enhances effective teaching and learning, the school environment is fairly the one that children could learn whiles playing as well as having a variety of materials to encourage meaningful experiences. These responses can be found in Table 2.

Table-2. Learning Environment of Early Childhood Descriptive

\begin{tabular}{|c|c|c|c|}
\hline & $\mathbf{N}$ & Mean & Std. Deviation \\
\hline $\begin{array}{l}\text { The classroom contains areas in which children can select and plan their } \\
\text { activities. }\end{array}$ & 136 & 2.31 & 0.735 \\
\hline The classroom has areas for quiet and active social interactions. & 136 & 2.14 & 0.732 \\
\hline The classroom setting is not over-stimulating. & 136 & 2.04 & 0.847 \\
\hline $\begin{array}{l}\text { The classroom contains clearly labelled areas with words and pictures to } \\
\text { encourage independence. }\end{array}$ & 136 & 2.01 & 0.834 \\
\hline The classroom has a variety of materials to encourage meaningful experiences. & 136 & 1.98 & 0.683 \\
\hline The school environment is one that children could learn whiles playing. & 136 & 1.93 & 0.785 \\
\hline The school environment enhances effective teaching and learning. & 136 & 1.68 & 0.629 \\
\hline \multicolumn{2}{|l|}{ Total } & 2.0128571 & 0.749285714 \\
\hline
\end{tabular}

Source: Ahmed Abdulai

Despite the positive feedback, participants also indicated as shown in Figure 2, that the classroom does not contain areas in which children can select and plan their own activities. Also, the classroom does not have areas for quiet and active social interactions but its setting is fairly stimulating.

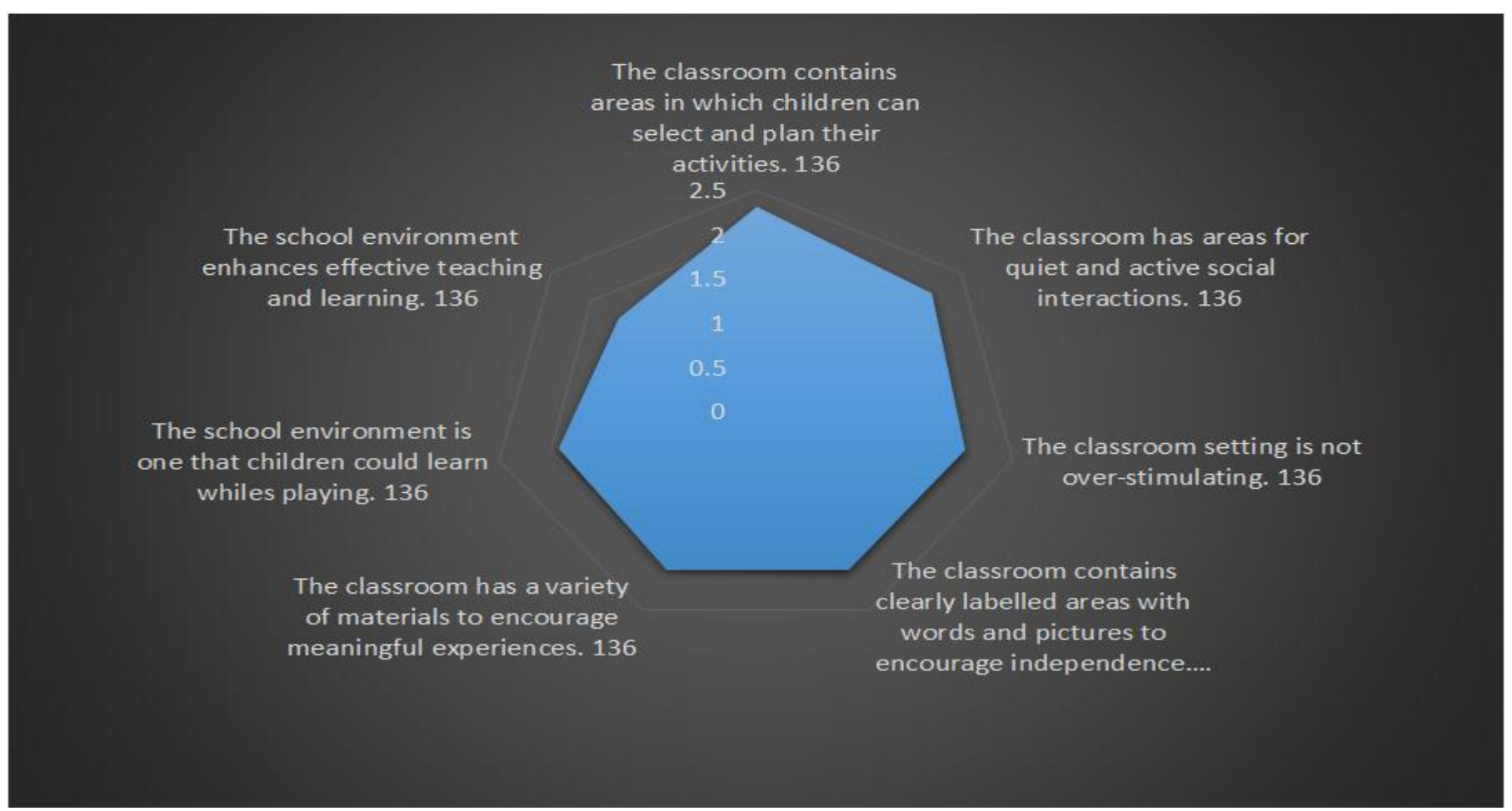

Source: Ahmed Abdulai

Figure-2. Learning Environment of Early Childhood Mean Radar Chart. 
With regards to instructional strategies used at early childhood centers which served as Research question three, responses were that instruction was used to promote learning with satisfactory scoring of 1.88 as shown in Table 3 . Respondents indicated that teaching is done through the use of L1 or English and children involvement in teaching is quite high

Table-3. Instructional Strategies Used in Early Childhood Centers Descriptive

\begin{tabular}{|c|c|c|c|}
\hline & $\mathbf{N}$ & Mean & Std. Deviation \\
\hline Teaching is teacher centred. & 136 & 2.66 & 0.647 \\
\hline Learners are allowed to choose and plan their own learning activities. & 136 & 2.38 & 0.688 \\
\hline Parents are involved in school activities. & 136 & 2.03 & 0.655 \\
\hline Children are allowed to learn at their own pace. & 136 & 1.95 & 0.744 \\
\hline Teaching is done through play. & 136 & 1.62 & 0.632 \\
\hline Children involvement in teaching. & 136 & 1.27 & 0.523 \\
\hline Teaching is done through the use of L1 or English. & 136 & 1.24 & 0.561 \\
\hline Total & & 1.8785714 & 0.635714286 \\
\hline
\end{tabular}

Source: Ahmed Abdulai

Nevertheless, respondents disagreed that learners are allowed to choose and plan their own learning activities, and also allowed to learn at their own pace. Respondents also responded negatively that parents are involved in school activities. These responses are presented in Figure 3.

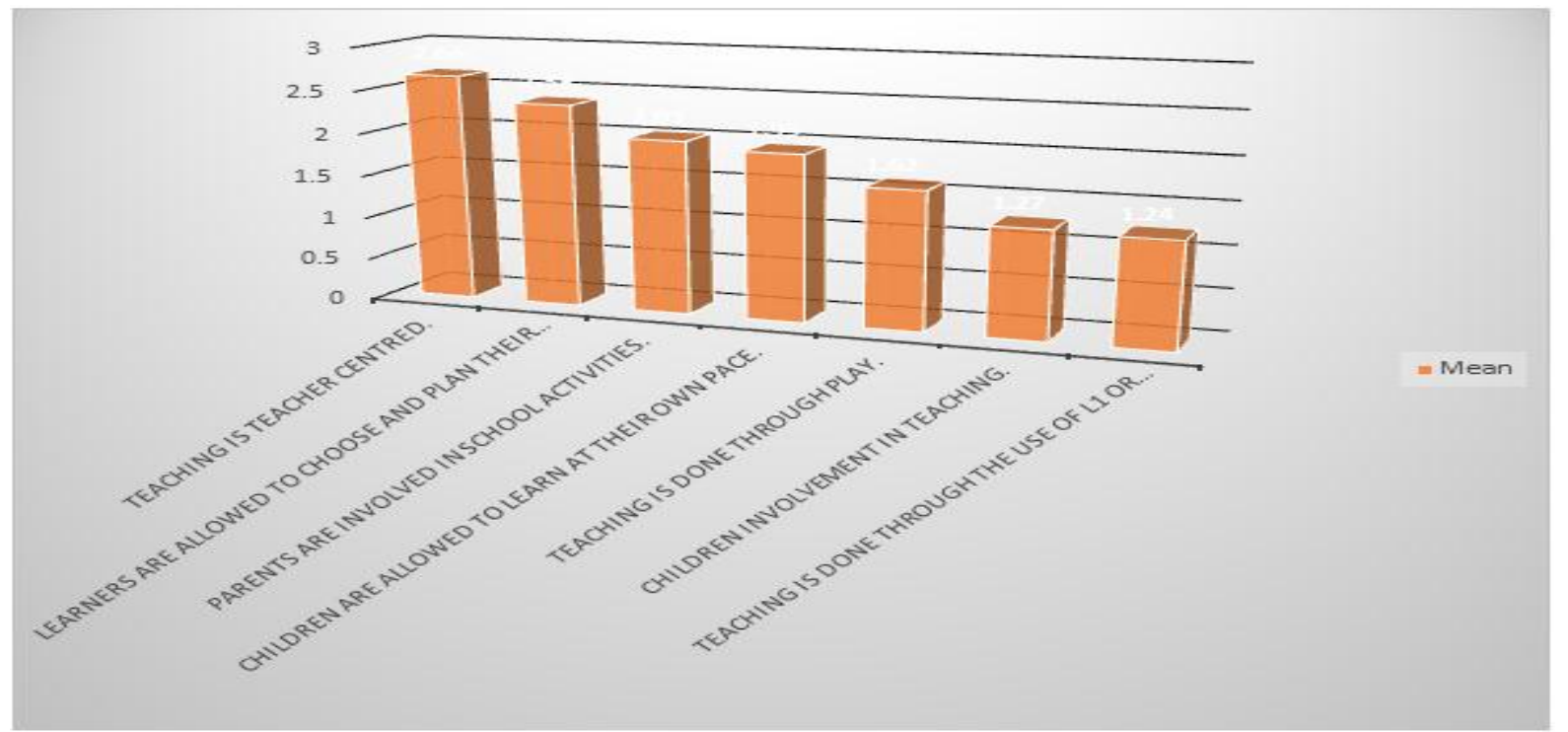

Source: Ahmed Abdulai

Figure-3. Instructional Strategies Used in Early Childhood Centers Mean Column Chart

Finally, on the question of the mode and place of assessment in early childhood education, respondents' impression on assessment procedures used at early childhood centers in Ghana as presented in Table 4 was that it is encouraging. Early childhood teacher-trainees of this study agreed that assessment helps to show progress and growth over time and it is basically used for promotion. In addition, they accepted that assessment is ongoing, with many opportunities for teachers to observe and reflect on learners' accomplishments.

Table-4. Assessment Procedures at Early Childhood Centers Descriptive

\begin{tabular}{|c|c|c|c|}
\hline & $\mathbf{N}$ & Mean & Std. Deviation \\
\hline Children who do not finish their work are not allowed to go on break. & 136 & 2.57 & 0.696 \\
\hline $\begin{array}{l}\text { Assessment includes anecdotal notes and observations to enhance curriculum } \\
\text { development. }\end{array}$ & 136 & 1.78 & 0.717 \\
\hline Assessments are paper and pencil based. & 136 & 1.73 & 0.856 \\
\hline $\begin{array}{l}\text { Teachers and parents share useful information about children's learning strengths and } \\
\text { needs. }\end{array}$ & 136 & 1.73 & 0.626 \\
\hline $\begin{array}{l}\text { Observation and evaluation of each learner's learning styles are keys to assessing } \\
\text { learning and growth. }\end{array}$ & 136 & 1.55 & 0.653 \\
\hline $\begin{array}{l}\text { Assessment is ongoing, with many opportunities for teachers to observe and reflect on } \\
\text { learners' accomplishments. }\end{array}$ & 136 & 1.53 & 0.608 \\
\hline Assessments are used for promotion. & 136 & 1.37 & 0.581 \\
\hline Assessment helps to show progress and growth over time. & 136 & 1.3 & 0.461 \\
\hline Total & & 1.695 & 0.64975 \\
\hline
\end{tabular}

Source: Ahmed Abdulai

Despite scoring 1.70 on the appropriateness of assessment at the early childhood level, respondents also disagreed that children who do not finish their work are not allowed to go on break and assessment includes anecdotal notes and observations to enhance curriculum development. Additionally, respondents generally disagreed that assessments are paper based (See; Figure 4). 


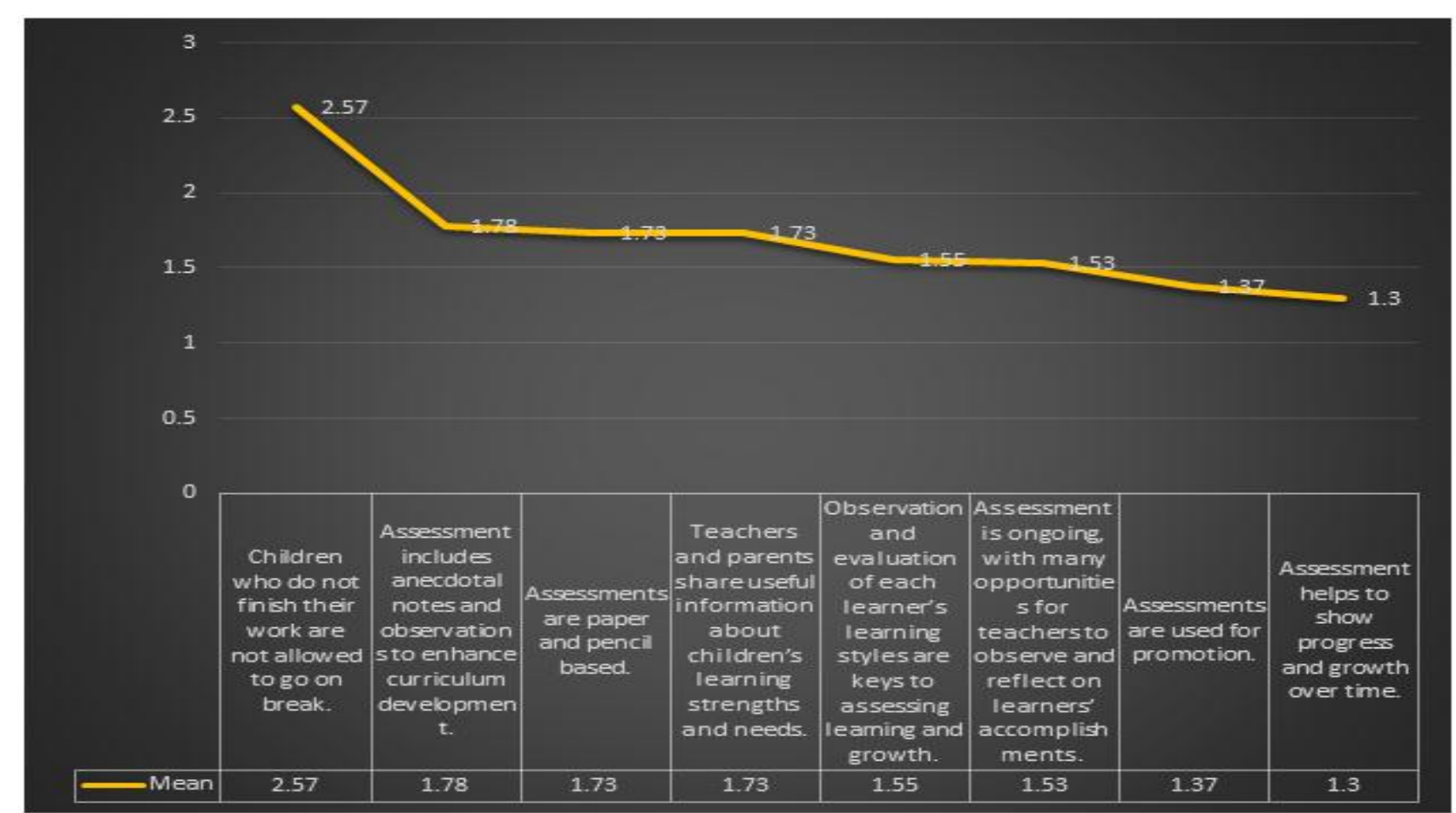

Source: Ahmed Abdulai

Figure-4. Assessment Procedures Used at Early Childhood Centers Mean Line Chart.

\section{Summary Conclusions and Recommendations}

This study aimed at presenting perspectives of early childhood teacher-trainees on activities at early childhood centers in Ghana in the areas of; curriculum content and its relevance to child development at early childhood centers, the nature and type of early childhood environments and their roles in stimulating learning, pedagogical practices at early childhood centers, and the nature and types of assessment tools at early childhood centers.

The study findings on the relevance of school curriculum encountered by participants shows clearly that they were quite satisfied with the content, relevance, and its place in the development of the learner. Indeed, the curriculum as observed by participants is tailored towards the total development of the learner, hence, confirming the position of Abrompah (2010) that Ghana's early childhood educational curriculum is shaped to develop the child physically, emotionally, spiritually, and cognitively. This notwithstanding, it is of concern that the findings of this study also reveal that children are required to acquire the same skills, thus departing from what most of the literature recommends (see; (Laevers, 1994; Dinnebeil et al., 2013)). Again, though the school environment was described to enhance teaching and learning, it is also the case that such environments especially the classroom did not allow for children to select their own activities, as well as interact socially. In addition, it is also revealing that pedagogy at the early childhood level though one that makes use of L1 and English language, and helps to promote learning, is also structured such that it deprives children of choice relative to what to learn, and also do not allow children to learn at their own pace. Comments by participants on the nature and uses to which assessment is put at best can be described as encouraging.

Overall, it is the conclusion of this study that participants who partook in this study are fairly satisfied with the curriculum, environment, instructional strategies, and assessment tools found at early childhood centers where they undertook their teaching internship programs. However, it is equally true that what is learnt at early childhood centers represented as curriculum is structured for learners to acquire the same information, and this is reinforced by classrooms that do not allow learners to learn at their own pace, and being able to select their own activities. This definitely deviates from what have always being held as idle practices of early childhood education; children learn efficiently when through learning of what interests them (Shepard et al., 1998). A curriculum program that makes room for the needs and interests of individual learners is necessary and this is a recommendation by this study. Though the early childhood curriculum can be universal as applies to kindergarten education in Ghana, it must also be modelled to meet the unique individual needs and capabilities of learners. This will mean educators will have to be equipped with skills and techniques of differentiated instruction. Again, information gathered through assessment must be shared with parents and as much as possible parental involvement in teaching and learning should be encouraged. Finally, classroom architecture for early childhood centers in Ghana must consider space for individual learning and activities.

It is worth stating, that this study does paint a picture of developmental appropriateness of early childhood education programs in Ghana. But it is also instructive that its findings are limited due to its scope. Observations by 136 early childhood educators who mostly taught at urban centers definitely cannot be a reflection of happenings in the entire country, Ghana. However, it is refreshing that though limited in scope as the study may be, it presents to stakeholders the opportunity to appreciate the activities that are taking place at some selected early childhood centers in Ghana especially in the areas of curriculum practices, environmental conditions, pedagogical practices, and assessment. This information limited as it may be, provide impetus in the areas of where efficient early childhood educational practices are challenged, and what can be done to address them.

\section{References}

Abrompah, W.K., 2010. Rudiments of curriculum construction and social change. Winneba: Watered Gardens Press.

Adentwi, K.I., 2005. Curriculum development: An introduction. Kumasi: Wilas Press Ltd.

Armstrong, T., 2006. The best schools: How human development research should inform educational practice. Alexandria, VA: Development Association for Supervision and Curriculum. 
Asemanyi, E.T. and D.V. Wunku, 2007. The status of early childhood care and development in Aboadze-Aboazi Township, Ghana. International Journal of Educational Research, 3(2): 237-248. View at Google Scholar

Barnett, W.S. and J.T. Hustedt, 2003. Preschool: The most important grade. Educational Leadership, 60(7): 54-57. View at Google Scholar

Bredekamp, S., 1987. Developmentally appropriate practice in early childhood programs serving children from birth through age 8. Washington, DC: NAEYC.

Bredekamp, S. and C. Copple, 1997. Developmentally appropriate practice in early childhood programs. Washington, DC: Children National Association for the Education of Young.

Bredekamp, S. and T. Rosegrant, 1995. Reaching potentials: Transforming early childhood curriculum and assessment. Washington, DC: National Association for the Education of Young Children, 2.

Crosser, S., 1996. The butterfly garden: Developmentally appropriate practice defined. Early Childhood News. Retrieved from http://www.earlychildhoodnews.com/earlychildhood/article_view.aspx?ArticleID=115.

Dewey, J., 1915. The school and society. Chicago: University of Chicago Press.

Dinnebeil, L., M. Boat and Y. Bau, 2013. Integrating principles of universal design into the early childhood curriculum. Dimensions of Early Childhood Education, 41(1): 3-14. View at Google Scholar

Dodge, D.T. and L.J. Colker, 1992. The creative curriculum for early childhood. Washington, DC: Teaching Strategies Inc.

Early Childhood Care and Education Policy, 2005. Ministry of women and children's affairs: Republic of Ghana. Available from https://s3.amazonaws.com/ndpc-static/pubication/Early+Childhood+Care+and+Development+Policy.pdf.

Elliott, S., 2010. Children in the natural world. In Davis, J. (Ed.), Young children and the environment: Early education for sustainability. Melbourne: Cambridge University Press. pp: 43-75.

Estes, L.S., 2004. Essentials of child care and early education. Boston: Allyn and Bacon, Inc.

Gandini, L., 1998. Educational and caring spaces. In C. Edwards, L. Gandini, \& G. Foreman (Eds.), The Hundred Languages of Children: The Reggio Emilia Approach - Advanced Reflections. Greenwich, CT: Able. pp: 161-178.

Hayes, C., J. Palmer and M. Zaslow, 1990. Who cares for America's children? child care policy for the 1990s. Washington, DC: National Academy Press.

Herbert, B.N., 2004. Mis-constructing knowledge: The case of learner-centred pedagogy in South Africa. Prospects, 34(3): 249-265. View at Google Scholar | View at Publisher

Hohman, M. and D.P. Weikart, 1995. Educating young children: Active learning practices for preschool and child care programs. Michigan: High/Scope Press.

Kellough, R.D. and N.G. Kellough, 1999. Secondary school teaching: A guide to method resources; planning for competence. NJ, Upper Saddle River: Prentice Hall.

La Paro, K.M., D. Sexton and P. Snyder, 1998. Program quality characteristics in segregated and inclusive early childhood settings. Early Childhood Research Quarterly, 13(1): 151-167. View at Google Scholar | View at Publisher

Laevers, F., 1994. Defining and assessing quality in early childhood education. Belgium: Laevers University Press.

Lubeck, S., 1998. Is developmentally appropriate practice for everyone? Childhood Education, 74(5): 283-292. View at Google Scholar| View at Publisher

Meisels, S.J., 2001. Fusing assessment and intervention: Changing parents' and providers' views of young children. Zero to Three, 21(4): 4-10. View at Google Scholar

Neisworth, J.T. and S.J. Bagnato, 2004. The mismeasure of young children: The authentic assessment alternative. Infants and Young Children, 17(3): 198-212. View at Google Scholar | View at Publisher

O'Brien, L.M., 1996. Turning my world upside down: How i learned to question developmentally appropriate practice. Childhood Education, 73(2): 100-102. View at Google Scholar

O'Sullivan, M., 2004. The reconceptualization of learner-centred approaches: A Namibian case study. International Journal of Educational Development, 24(6): 585-602. View at Google Scholar $\mid$ View at Publisher

Obiadike, N.D. and J.O. Enemuo, 2013. The role of teachers of young children in ensuring developmentally appropriate practice in early childhood education curriculum implementation. Journal of Emerging Trends in Educational Research and Policy Studies, 4(5): 821826. View at Google Scholar

Shams, L. and A.R. Seitz, 2008. Benefits of multisensory learning. Trends in Cognitive Sciences, 12(11): 411-417. View at Google Scholar| View at Publisher

Shepard, L.A., S.L. Kagan and E. Wurtz, 1998. Principles and recommendations for early childhood assessments. Washington, DC: National Goals Panel.

Siraj-Blatchford, I., 1999. Early childhood pedagogy, practice, principles and research' in P. Mortimore (Ed) Understanding Pedagogy and its Impact on Learning. London: Paul Chapman.

Tanner, D. and L. Tanner, 1995. Curriculum development. Theory into practice. New Jersey: Englewood Cliffs.

Tomlinson, C.A., 2001. How to differentiate instruction in mixed-ability classrooms. 2nd Edn., Alexandria, VA: ASCD.

Tracey, D. and L. Morrow, 2012. Lenses on reading: An introduction to theories and models. New York: Guilford Press.

\section{Bibliography}

Berk, L., 1985. Relationship of educational attainment, child oriented attitudes, job satisfaction, and career commitment to caregiver behaviour toward children. Child Care Quarterly, 14(23): 103-129. View at Google Scholar | View at Publisher

ECCEP, 2005. Ministry of women and children's affairs: Republic of Ghana. Available from https://s3.amazonaws.com/ndpc$\underline{\text { static/pubication/Early+Childhood+Care+and+Development+Policy.pdf. }}$ 